\title{
Knowledge Level of Students About Traffic at Public Junior High School (SMP Negeri) 3 Candi Sidoarjo
}

\author{
Rinda Listya Antari ${ }^{1, *}$ Listyaningsih ${ }^{2}$ \\ ${ }^{1,2}$ Universitas Negeri Surabaya
}

"Corresponding author.Email: rindalistya@gmail.com

\begin{abstract}
Traffic education is very important for students since elementary school and junior high school (SMP) because traffic accidents involving students are getting higher every year. One of the causes of traffic accidents is the lack of knowledge that drivers have about traffic. The purpose of this study was to describe the level of knowledge of students about traffic at SMP Negeri 3 Candi Sidoarjo. This research is quantitative. The research population is all students at SMP Negeri 3 Candi Sidoarjo for the 2020/2021 academic year, totaling 786 students. The sample used was 90 students in grades VII, VIII, and IX. The sampling technique used a disproportionate stratified sampling technique. Data collection techniques using a questionnaire. The results showed that the level of knowledge of students about traffic at SMP Negeri 3 Candi Sidoarjo was in the high category as many as 47 students, 43 students in the medium category, and no students in the low category. So, the level of knowledge of students about traffic at SMP Negeri 3 Candi Sidoarjo is concluded in the high category. This proves that the implementation of traffic education has been carried out well in terms of the level of knowledge achieved by students.
\end{abstract}

Keywords: knowledge level, traffic

\section{INTRODUCTION}

Science and Technology (IPTEK) which can help humans to be able to work more quickly and efficiently is now starting to develop over time. One of the rapid developments in Science and Technology (IPTEK) is transportation, people are now starting to switch from public transportation to private transportation such as motorcycles and cars. Private transportation causes traffic jams that occur everywhere. This congestion causes everyone to do various things to get through the traffic jam even if it has to violate traffic.

This increasing number of private vehicles eventually causes traffic jams. Drivers of private vehicles caused most accidents (37\%). Most drivers (46\%) were aged 20-30 years[1]

- The government has made a regulation which is a traffic regulation Law no. 22/2009 so that the traffic situation remains conducive, but in reality, there are still many road users who do not comply with these rules.[2]

Based on data from the Directorate General of Land Transportation of the Ministry of Transportation, the profile of accident victims in Indonesia in 2020 based on the level of education obtained data that the largest accident victims were students with a high school education level of 80,641 people, 17,699 junior high schools, and 12,557 elementary school students. Meanwhile, for the D3 education level there are 770 people, S1 there are 3,751 people, and S2 there are 136 people [3].

Based on the results of research from Indriastuti, A.K., and Sulistio, H (2010:255) it is known that the factors that influence the possibility of motorcycle riders having an accident are gender, the number of motorcycles owned, destination trip, distance, and driving knowledge[4]. Knowledge is one of the causes of traffic accidents because the lack of knowledge possessed by the driver will certainly make the driver careless in driving. Traffic knowledge should be well understood by every driver this is because good knowledge will lead individuals to behave well too.

According to research by Lisnawati states that in Sidoarjo Regency, traffic violations committed by students have increased every year[5]. Sugiyanto and Santi stated that one method that can be used to increase awareness and culture of traffic safety is through education[6]. So education is used as a preventive effort to reduce the number of traffic violations because with traffic education from an early age it is hoped that 
it will be embedded in the individual and will become a habit. then the MoU Decree No.03/III/KB/2010 and No. B/9/III/2010 concerning Traffic Education in National Education.

Students at the junior high school level are used as subjects in this study because at that level psychologically a person enters the early teenage stage, namely in the age range of 12-15 years. In this early teenage stage, a person has a desire to do new things that they have never done before. Like riding a motorcycle, in a survey conducted on 80 students at SMP Negeri 3 Candi Sidoarjo, it was found that as many as $64 \%$ of students at the school were able to ride a motorcycle and $23 \%$ of them had ridden a motorcycle on the highway. So traffic education is started to be given at the junior high school level as a provision for students to understand more about ethics in traffic which will begin to be practiced immediately when they already have a driver's license, namely at the age of 17 years or at the high school level (SMA).

Based on the results of the research by Listyaningsih, et al states that the knowledge of the Surabaya State University Laboratory Junior High School Students about Traffic Regulations for students in class VII, class VIII, and class IX shows that the knowledge of students at the school is still low[7]. So the integration of traffic education into Civics subjects is expected to be able to provide a better understanding related to traffic so that a good understanding of traffic will make students more orderly in traffic. This research was conducted at SMP Negeri 3 Candi Sidoarjo because the school has implemented integrated traffic education into Civics subjects since 2018. Based on the facts described above, it is important to conduct this research to determine the level of knowledge of students about traffic at SMP Negeri 3 Candi Sidoarjo.

This study uses the cognitive development theory of Jean Piaget. This theory explains about the knowledge that a person has will experience development by going through several stages based on the age range. The higher a person's age, the more complex his knowledge will be. In Ekawati, M (2019:2), it is explained that Piaget distinguishes the stages of cognitive development into 4 stages, namely: sensorimotor stage (0-2 years), pre-operational stage (2-6 years), concrete operational stage (6-12 years). ), and the formal operational stage (12 years and over) [8]. This study will focus on the last stage, namely the formal operational stage because the subjects in the study who are junior high school students aged 12-15 years are included in that stage. For junior high school students who have entered the formal operational stage, it is considered that the construction of their thinking is more complex and mature so that they have broader knowledge. This is in line with the opinion of Ekawati, M (2019: 2), that at the formal operational stage children can reason about things that are abstract, able to understand and use symbols, create ideas, and understand concepts.

\section{METHODS}

This research is quantitative descriptive research using percentages. Data collection techniques using a list of questions. The collected data will be analyzed using descriptive statistical techniques and is expressed as a percentage. based on calculations using the Slovin formula with a significance level of $90 \%$ obtained a total sample of 90 students. In this study, the sample was taken using a disproportionate stratified sampling technique, namely taking a stratified sample based on a certain level and dividing the sample size equally at each level without regard to the comparison of the number of subpopulations. Then it can be determined that the sample size is 30 students at each grade level, both class VII, class VIII, and class IX.

The variable in this study is the level of knowledge of students about traffic. The operational definition of the variable is the level of information received and embedded in the minds of each student regarding all matters related to human relations, whether using tools or not, which makes the road space for movement. As for knowing the level of knowledge of students about traffic, 6 material indicators are used by the modules that have been taught at school, namely: understanding, traffic signs, road markings, traffic violations and sanctions, traffic components, and traffic procedures.

The instrument consists of 40 items, scoring is done by giving a score of 0 on the wrong answer and a score of 1 on the correct answer so the highest score that can be obtained by the respondent is 40 and the lowest score that can be obtained by the respondent is 0 . The difference in scores is then divided into 3 categories so that the interval for each group is $40: 3=$ 13.3 rounded becomes 13 , then the criteria used are:

Table 1. Categories of Students' Knowledge Levels About Traffic

\begin{tabular}{ccc}
\hline category & interval & percentage \\
\hline high & $28-40$ & $68 \%-100 \%$ \\
\hline medium & $14-27$ & $34 \%-67 \%$ \\
\hline low & $0-13$ & $0 \%-33 \%$ \\
\hline
\end{tabular}

\section{RESULTS AND DISCUSSION}

Based on the results of filling out the questionnaire conducted by students of SMP Negeri 3 Candi Sidoarjo, the results were obtained in the form of the following table:

Table 2. Total Score of Knowledge Level About Traffic

\begin{tabular}{cccc}
\hline category & interval & percentage & trequency \\
\hline high & $28-40$ & $68 \%-100 \%$ & 47 \\
\hline medium & $14-27$ & $34 \%-67 \%$ & 43 \\
\hline low & $0-13$ & $0 \%-33 \%$ & 0 \\
\hline Total & 90 \\
\hline Average & 28 \\
\hline
\end{tabular}

Source: research primary data

Based on table 2, it is known that 47 students get an interval score of 28-40 or are included in the high category, then 43 students get an interval score of 14-27 or are included in the medium category, and there are no students who get a score interval $0-13$ or included in the low category.

Based on the tabulation results, it is known that the highest score obtained by students is 39 , while the lowest 
score obtained by students is 15 . The average score obtained by students is 28 . When matched with table 1 , the category of students' level of knowledge about traffic then the average score is included in the high category. So it can be said that the students of SMP Negeri 3 Candi Sidoarjo have a high level of knowledge about traffic which is included in the high category. This means that students of SMP Negeri 3 Candi Sidoarjo who have received traffic education through Pancasila and Civics Education subjects have been able to understand most of the material related to traffic so they have good knowledge about traffic. Traffic signs are the material that gets the lowest score, which is $61 \%$. This means that students of SMP Negeri 3 Candi Sidoarjo have a poor understanding of the material related to traffic signs.

The score for the level of knowledge of students about traffic is obtained from the results of 6 indicators of traffic education material that have been taught and contained in the module used by Pancasila and Civics Education teachers at SMP Negeri 3 Candi Sidoarjo, the six material indicators are material 1 understanding, nature and traffic objectives, material 2 traffic signs, material 3 road markings, material 4 violations and traffic sanctions, material 5 traffic components and material 6 traffic procedures. The scores for each indicator will be presented in the following graphic form to make it easier to read the data.

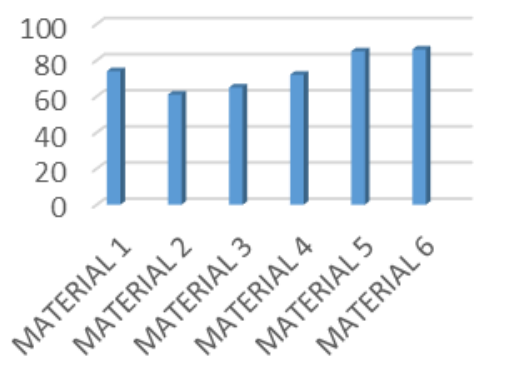
Graph 1. Total Percentage of Score for Each Material
Indicator

Based on graph 1, it is known that the material that gets the highest score is material 6 which is about traffic procedures which gets a percentage score of 86 . This proves that students of SMP Negeri 3 Candi Sidoarjo have a good understanding of the material related to traffic procedures.

While the material that received the lowest score was material 2 which is about traffic signs which got a percentage score of 61. This means that students of SMP Negeri 3 Candi Sidoarjo have a poor understanding of the material related to traffic signs.

The details of the scores per indicator in each class, both class VII, VIII, and IX will be presented in the following graphic form:

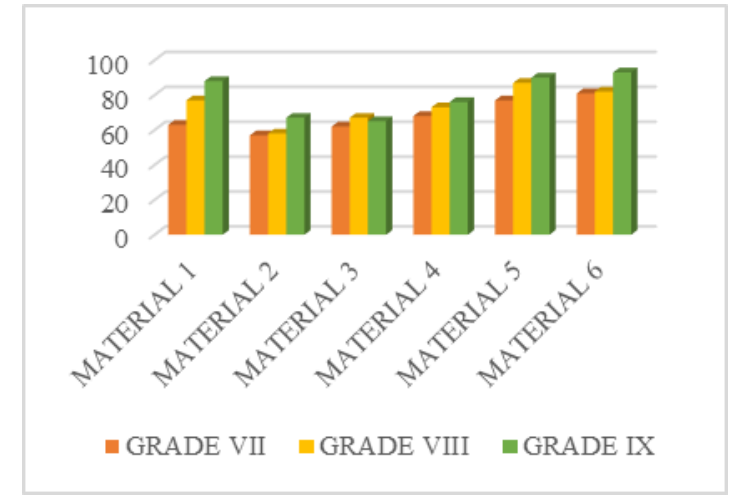

Graph 2. Percentage of Score on Each Material Indicator

Based on graph 2, it can be seen that the score on each material on average is getting higher in line with the higher grade level. This can be seen in graph 5 regarding materials 1 , $2,4,5$, and 6 , in the graph it can be seen that the score is increasing in line with the grade level where class VII gets the lowest score, followed by class VIII then the highest score is obtained by class IX. Based on the graph above, it can be concluded that the level of knowledge of students about traffic is getting higher in line with the higher grade levels and age of students.

The students of SMP Negeri 3 Candi Sidoarjo who are 1215 years old are included in the formal operational stage or the last stage of development according to Jean Piaget. At this stage, students are considered to have been able to understand concepts and can think abstractly. The concepts related to the traffic that has been taught by teachers through traffic education integrated into Pancasila and Civics Education subjects have been able to be understood well by students, this is evidenced by the level of knowledge of students about traffic in table 2 which shows that the score level of knowledge is equal to $70 \%$ are included in the high category.

Students at SMP Negeri 3 Candi Sidoarjo get scores that fall into the high category, it can be said that the process of assimilation, accommodation, and equilibration in students has gone well so that students' knowledge of traffic gets good results. also. The results of this study are in line with this theory which explains that the development of children's thinking is strongly influenced by the age of the child. Based on the results of this study, it can be seen that the higher the age of the child, the better the thinking process and the better his understanding of something. This can be proven by the results of the level of knowledge of students about traffic where the average percentage score for class VII is $65 \%$, class VIII is $70 \%$ and class IX is $75 \%$.

The implementation of traffic education in schools can be considered successful because the level of knowledge or understanding of students related to traffic is included in the high category. With the successful implementation of traffic education which is integrated into this Pancasila and Civics 
Education subject, it is hoped that the knowledge already possessed by these students can later be put into practice directly when they have entered the minimum age to be able to obtain a driver's license to drive on the highway.

\section{CONCLUSION}

Based on the results of the study which revealed that the level of knowledge of students about traffic at SMP Negeri 3 Candi Sidoarjo was included in the high category with an average score of $70 \%$. The material that has the highest score or can be said to be the material that is most widely understood by students is material about traffic procedures and the material that gets the lowest score or is less understandable by students is material related to traffic signs. This proves that the implementation of traffic education learning that is integrated into Civics subjects can be said to be successful because the level of knowledge of students about traffic at SMP Negeri 3 Candi Sidoarjo is included in the high category.

\section{REFERENCES}

[1] Akway M. Cham, Anthony Lasuba, Riing Y. Chan, Angelo L. Jockmet, Asmaa S. Korokon, et el, "Causes of Road Traffic Accident in Juba", vol 10, no 2, pp. 3739,2017

[2] Listyaningsih, I.M. Suwanda, R. Wijaya, "Orderly Traffic Attitude Of Students Junior High School Laboratory Universitas Negeri Surabaya, vol 383, pp. 335-338,2019 [2nd International Conference on Social Science (ICSS 2019)

[3] Direktorat Jenderal Perhubungan Darat., "Korban Kecelakaan Lalin Didominasi Usia Produktif, Menhub Ajak Para Pelajar Selalu Disiplin Berlalu Lintas Dan Utamakan Aspek Keselamatan,” (Online),2021 (http://dephub.go.id/post/read/korban-kecelakaan-lalindidominasi-usia- produktif,-menhub-ajak-para-pelajarselalu-disiplin-berlalu-lintas-dan- utamakan-aspekkeselamatan?language $=\mathrm{id}$ accessed on 15 September 2021)

[4] Indriastuti, A.K., and Sulistio, H, "Influencing Factors on Motorcycle Accident in Urban Area of Malang, Indonesia", vol. 2. no. 5, pp. 252- 255,2010

[5] Lisnawati, E.'Tanggapan Peserta Didik SMA Kemala Bhayangkari 3 Pusdik Sabhara Porong Tentang Pendidikan Lalu Lintas,"vol 07,no 02, pp. 903-917,2019

[6] Sugiyanto, S and Santi, M, "Karakteristik Kecelakaan Lalu Lintas Dan Pendidikan Keselamatan Berlalu lintas Sejak Usia Dini (Studi Kasus Di Kabupaten Purbalingga)," vol 18, no 1, pp. 65-75,2015

[7] Listyaningsih, I.M. Suwanda, R. Wijaya, "Pengetahuan Peserta Didik SMP Laboratorium Universitas Negeri Surabaya Tentang Peraturan Lalu Lintas”, pp. 175-182, 03 November 2018 [Prosiding dalam Seminar Nasional Pendidikan IPS FISH UNESA dengan tema Pendidikan Indonesia Menyongsong Revolusi Industry 4.0, Surabaya]

[8] Ekawati, M, "Teori Belajar Menurut Aliran Psikologi Kognitif Serta Implikasinya Dalam Proses Belajar dan Pembelajaran,” vol 7,no.4, pp. 1-12,2019 